\title{
Comparing energy signature analysis to calculated $U$-values in wooden houses in a cold climate
}

\author{
G. Nordström, S. Lidelöw \& H. Johnsson \\ Division of Structural and Construction Engineering, \\ Luleå University of Technology, Sweden
}

\begin{abstract}
In Sweden the housing sector stands for about $40 \%$ of energy usage. About $20 \%$ of total energy usage goes to heating and hot tap water. Since 1920, the dominant building technology for single family houses in Sweden is a light timber-frame structure with studs at even spacing. This study aims to investigate how the static energy signature model can be used to estimate the effective U-values in existing wooden buildings and compare them to calculated U-values based on the thermal properties of the building parts. The results show that the energy signature model gives reasonable estimates of the U-value in a building. It is important though that a large difference in temperature can be achieved.

Keywords: energy signature, building energy use, houses in cold climate, average $U$-values.
\end{abstract}

\section{Introduction}

Northern Sweden has a subarctic climate. The harsh climate poses great demands on the climatic shell of residential buildings. Since 1920, the dominant building technology for single family houses in Sweden is a light timber-frame structure with studs at even spacing. Later years saw thicker walls with one or two horizontal layers of studs (Nordling and Reppen [1]). In Sweden the housing sector stands for about $40 \%$ of the energy usage. About $20 \%$ of total energy usage goes to heating and hot tap water (Energimyndigheten [2]). Since the oil crisis in the 1970s the energy usage has been a factor to consider when building houses. 
Measurements of the energy usage can be made with different methods, but often entail measuring many different parameters in the building. A method that offers the possibility to estimate the total U-value of the building envelope is the energy signature, where the overall power loss is measured together with the temperature difference. By plotting the power loss against the temperature difference, the slope of the resulting line is the total U-value times the envelope area of the building (K), (Sjögren et al. [3]). The energy signature model comes in two different versions; a static and a dynamic, where the dynamic model takes into account the dynamic thermal performance in the building parts.

This study aims to investigate how the static energy signature model can be used to estimate the effective U-values in existing wooden buildings and compare them to calculated U-values based on the thermal properties of the building parts.

\section{Theory}

\subsection{Energy signature}

Energy signature models estimate the overall power loss $(\mathrm{K})$ depending on the difference between indoor temperature $\left(\mathrm{T}_{\mathrm{i}}\right)$ and outdoor temperature $\left(\mathrm{T}_{\mathrm{e}}\right)$ as described by (Sjögren [4]) and (Hammarsten [5]):

$$
K\left(T_{i}-T_{e}\right)=P_{H}+P_{G}-P_{D Y N}
$$

where $(\mathrm{K})$ is the sum the of transmission and ventilation heat losses for the building, $\mathrm{P}_{\mathrm{H}}$ is the power supplied for heating, $\mathrm{P}_{\mathrm{G}}$ is the gained free power and $P_{\text {DYN }}$ is the dynamically stored/released power. If the heat is supplied via district heating $\mathrm{P}_{\mathrm{H}}$ consists of the power for district heating $\left(\mathrm{P}_{\mathrm{DH}}\right)$, power for hot water $\left(\mathrm{P}_{\mathrm{DHW}}\right)$ and the losses in the system $\left(\mathrm{P}_{\mathrm{L}}\right)$ :

$$
\mathrm{P}_{\mathrm{H}}=\mathrm{P}_{\mathrm{DH}}-\mathrm{P}_{\mathrm{DHW}}-\mathrm{P}_{\mathrm{L}}
$$

The gained free power $\left(\mathrm{P}_{\mathrm{G}}\right)$ consists of power contributions from insolation $\left(\mathrm{P}_{\mathrm{SUN}}\right)$, household electricity $\left(\mathrm{P}_{\mathrm{HE}}\right)$, household operating electricity $\left(\mathrm{P}_{\mathrm{BE}}\right)$ and power gains from people $\left(\mathrm{P}_{\mathrm{P}}\right)$ :

$$
\mathrm{P}_{\mathrm{G}}=\mathrm{P}_{\mathrm{SUN}}+\mathrm{P}_{\mathrm{HE}}+\mathrm{P}_{\mathrm{BE}}+\mathrm{P}_{\mathrm{P}}
$$

$\mathrm{K}$ can then be described:

$$
\begin{gathered}
K\left(\mathrm{~T}_{\mathrm{i}}-\mathrm{T}_{\mathrm{e}}\right)=\mathrm{P}_{\mathrm{DH}}-\mathrm{P}_{\mathrm{DHW}}-\mathrm{P}_{\mathrm{L}}+\mathrm{P}_{\mathrm{SUN}}+\mathrm{P}_{\mathrm{HE}}+\mathrm{P}_{\mathrm{BE}}+\mathrm{P}_{\mathrm{P}}-\mathrm{P}_{\mathrm{DYN}} \\
P_{T O T}=P_{D H}-P_{D H W}-P_{L}+P_{S U N}+P_{H E}+P_{B E}+P_{P}-P_{D Y N}
\end{gathered}
$$

where $\mathrm{K}$ equals $\mathrm{P}_{\text {тот }}$ :

$$
\mathrm{K}\left(\mathrm{T}_{\mathrm{i}}-\mathrm{T}_{\mathrm{e}}\right)=\mathrm{P}_{\text {TOT }}
$$




\subsection{Theoretical calculations}

The average $U$-value of the building envelope $U_{m}$ is calculated by equation (7) (Boverket [6])

$$
U_{m}=\frac{\sum_{i=1}^{n} U_{i} A_{i}+\sum_{k=1}^{m} l_{k} \Psi_{k}+\sum_{j=1}^{p} \chi_{j}}{A_{o m}}
$$

where $U_{i}\left(W / m^{2} K\right)$ is the heat transfer coefficient for a building element and $A_{i}$ $\left(\mathrm{m}^{2}\right)$ the area for that same building element. $\Psi_{\mathrm{k}}\left(\mathrm{W} / \mathrm{m}^{2} \mathrm{~K}\right)$ represents the heat transfer coefficient for linear thermal bridges and $l_{\mathrm{k}}$ represents the length of the cold bridge $(\mathrm{m}) \cdot \chi_{\mathrm{j}}(\mathrm{W} / \mathrm{K})$ concerns point losses. $\mathrm{A}_{\mathrm{om}}$ is the enclosing area of the building envelope.

\section{Method}

The terms in the energy signature model in eqn. (1) were measured and estimated in six buildings, Table 1. The buildings are all located in Luleå in Northern Sweden. This effective U-value is then compared to $U_{m}$ determined by eqn. (7).

Table 1: $\quad$ Properties of studied houses.

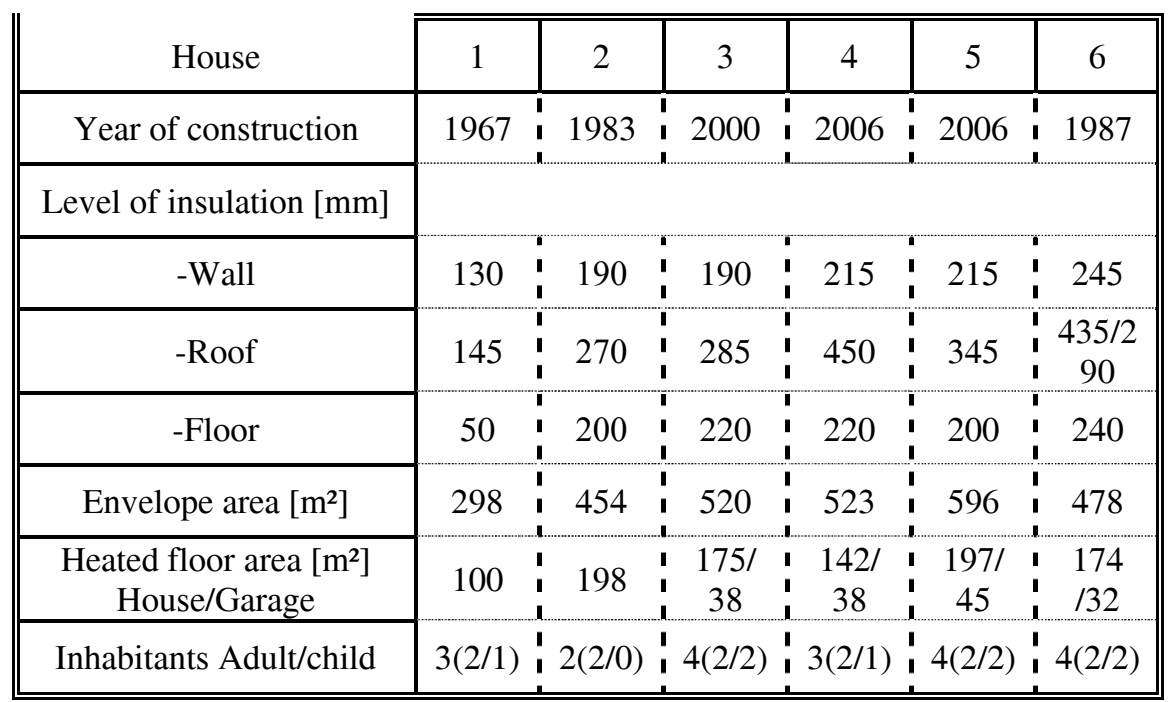

\subsection{Energy signature method}

By plotting the total power usage $\left(\mathrm{P}_{\mathrm{TOT}}\right)$ for heating in a house versus the difference in outside and inside temperature $(\Delta \mathrm{T})$ a power-temperature graph is produced. $\mathrm{K}_{\mathrm{TOT}}$ is then represented as the slope of the curve $\mathrm{P}_{\mathrm{TOT}} / \Delta \mathrm{T}(\mathrm{W} / \mathrm{K})$ calculated with a regression analysis (Montgomery [7]) (Figure 1). By dividing 


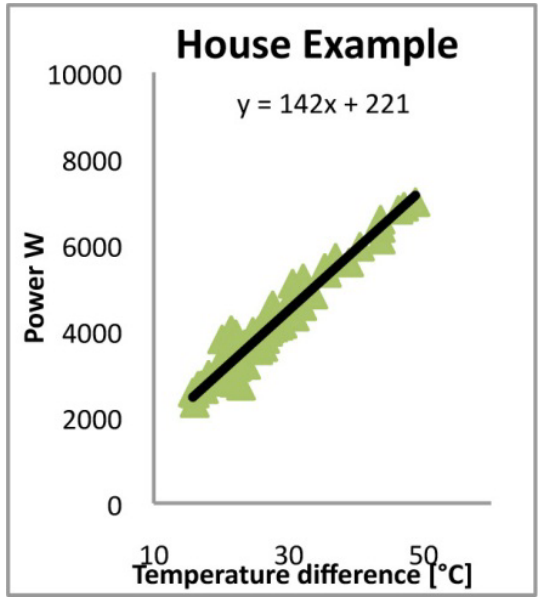

Figure 1: $\quad$ Example of PTOT/ $\quad \mathrm{T}(\mathrm{W} / \mathrm{K})$ graph of a studied house.

$\mathrm{K}(\mathrm{W} / \mathrm{K})$ with the envelope area $\left(\mathrm{m}^{2}\right)$ the effective $\mathrm{U}$-value is calculated $\mathrm{K} / \mathrm{A}_{\text {om }}$ $\left(\mathrm{W} / \mathrm{m}^{2} \mathrm{~K}\right)$.

The variables needed to determine $\mathrm{P}_{\mathrm{TOT}}$, eqn. (5) were checked for their dependency on the outdoor temperature. The variables depending on the outdoor temperature contribute to $\mathrm{K}$, while the variables with no dependency of the outdoor temperature move the curve up and down in the Y-direction.

A Saber measurement system (KYAB, Sweden) gathers data from sensors and uploads it to a web server. The Saber system collects data from district heating, indoor and outdoor temperature as well as electricity usage. The system samples once every minute and later converts the data to daily averages.

Temperatures $\left(\mathrm{T}_{\mathrm{i}}, \mathrm{T}_{\mathrm{e}}\right)$ were measured with factory calibrated sensors that read $-40 \mathrm{C}^{\circ}$ to $+80 \mathrm{C}^{\circ}$ with an accuracy of $\pm 0,1 \mathrm{C}^{\circ}$. Indoor sensors are placed in the living room or hallway where the interference from other heat sources is minimal. The outdoor sensor is placed on the façade to minimise effects from direct sunlight.

District heating usage is collected by reading the data via the IR port on the monitoring equipment. This data is collected as total usage of district heating and is later separated with a $10 \%$ accuracy into hot water $\left(\mathrm{P}_{\mathrm{DHW}}\right)$ and heating $\left(\mathrm{P}_{\mathrm{DH}}\right)$ by the Saber unit (Yliniemi [8]). The measurement is taken where the district heating pipes enter the building so all heat losses inside the building contribute to heating thus $\mathrm{P}_{\mathrm{L}}$ can be considered to be zero. $20 \%$ of the hot water heat can be assumed to contribute to the heating of the house (Petersson [9]).

Electricity usage is collected with a pulse detector on the electricity suppliers monitoring device. This records all electricity in the household and no separation of $\mathrm{P}_{\mathrm{HE}}$ and $\mathrm{P}_{\mathrm{BE}}$ is possible with the current installation. $75 \%$ of the electricity usage can be assumed to contribute to heating (Petersson [9]).

All studied buildings are wooden frame houses. Thus they all have a light frame with low thermal mass. This together with the usage of daily averages for all collected data means that the dynamics in the building can be assumed to 
have a minimal effect. A test where the average power for heating of two days was compared to the first of the two days show a difference of $6 \%$. This together with recommendations by (Hammarsten [5]) strengthens the assumption that the dynamics is covered by using daily averages in light frame houses.

The measurement period November to February is used for two reasons. Firstly, during this period temperature differences $(\Delta \mathrm{T})$ from $15 \mathrm{C}^{\circ}$ to over $50 \mathrm{C}^{\circ}$ occurs. Secondly, during this time period northern Sweden receives very few sun hours with low heat gain. Thus the effect gains from the sun $\left(\mathrm{P}_{\mathrm{SUN}}\right)$ can be assumed to be minimal, (Sjögren et al. [3], SMHI [10]).

A human is assumed to produce $71 \mathrm{~W}$ when idling and $119 \mathrm{~W}(\mathrm{Pp})$ when active (Sauer et al. [11]). They are further assumed to spend eight hours idling, eight hours active and eight hours away from home all seven days in the week. No differences are assumed between children and adults.

\subsection{Theoretical calculations}

To identify sizes of building parts and their composition, façade and structural drawings were used. Thermal properties for the building materials were taken from (Petersson [9]). An estimation was made concerning the age of windows and doors, applying tabulated values. Values for linear thermal bridges were taken from (Petersson [9]). Point losses were neglected in the current work.

\section{Results and analysis}

\subsection{Energy signature method}

Figure 2 show if the variables depend on the outdoor temperature. Figure 3 shows the difference between $\mathrm{K}$ considering all variables and $\mathrm{K}_{\mathrm{H}}$ when considering only the effect from heating $\mathrm{P}_{\mathrm{DH}}$ for one of the studied houses. It is clear that heat have a major effect on $\mathrm{K}$. Hot water production and electricity does not depend on the outdoor temperature and the residents are assumed to not suddenly go away or stay home more in any systematic way when the temperature changes. All houses show very similar characteristics and the difference between $\mathrm{K}$ and $\mathrm{K}_{\mathrm{H}}$ varies up to $7 \%$ for all houses except house 6 , which is $30 \%$ off.

Table 2 shows both the calculated U-value and the effective U-value for all six houses. For all houses except house 1 the theoretical U-values are higher or the same as the effective U-value, House 2 is the only house with a very large difference between the two that does not show up in the parameter study. Figure 4 shows how the variables depend on the outdoor temperature for house 6 . It can be seen that electricity depends on the outdoor temperature and thus influences K. By adding $75 \%$ of the electricity as heat gains (Petersson [9]) K rises from $150 \mathrm{~W} / \mathrm{K}$ to $194 \mathrm{~W} / \mathrm{K}$, which yields an effective U-value of 0,41 . From tables 1 and 2 it can be seen that buildings with a larger envelope area produce lines with a higher slope. It can also be seen from Figure 5 that the house two to five al have higher theoretical then effective U-values. 


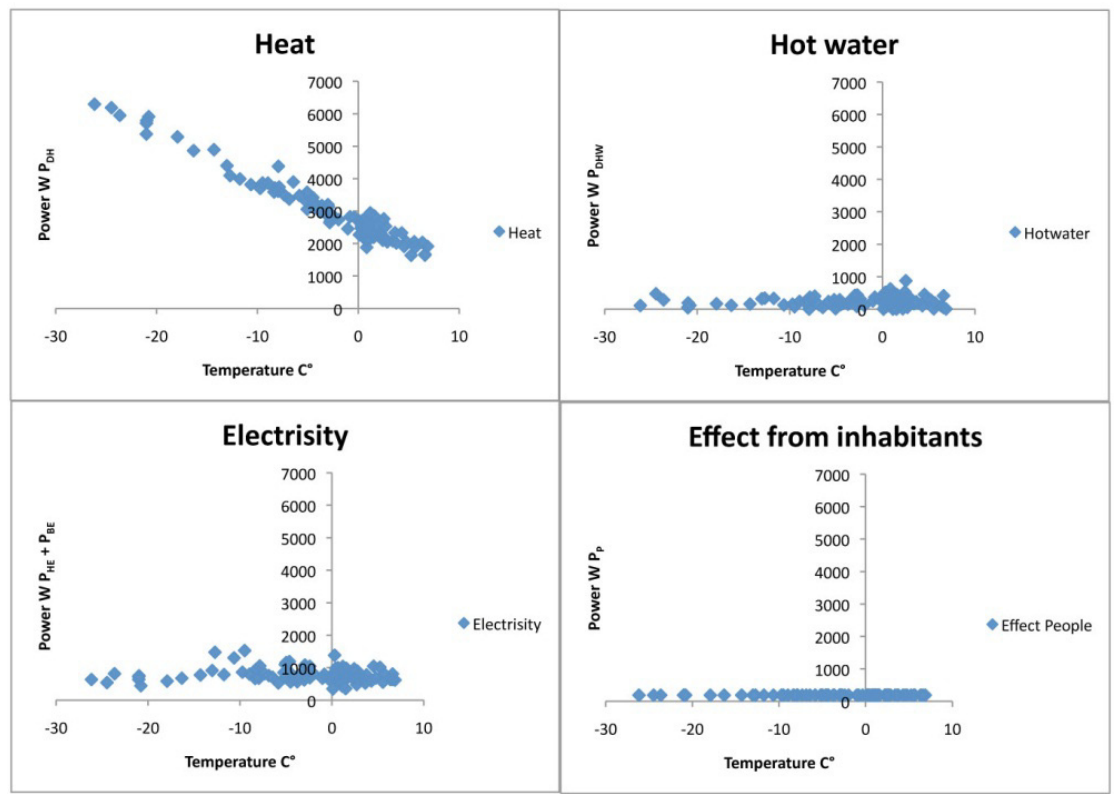

Figure 2: $\quad$ Variables dependency to outdoor temperature.

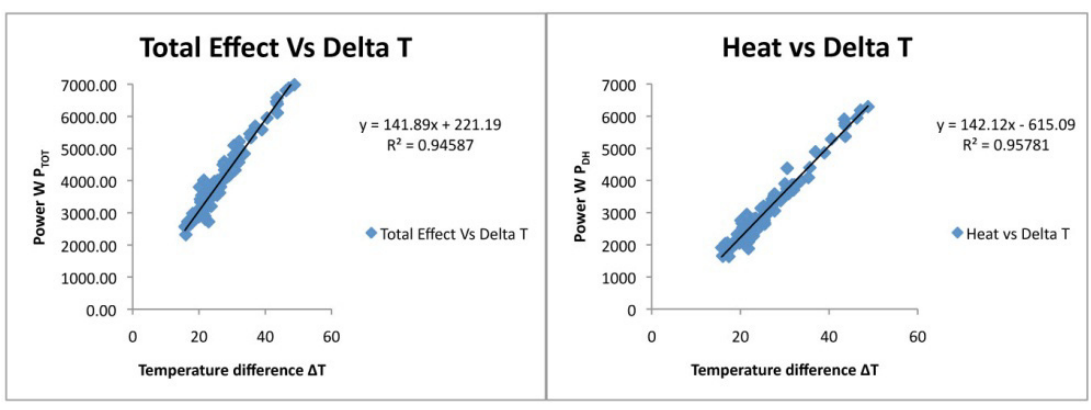

Figure 3: Graphs showing difference between slope of $\mathrm{K}$ (left) and $\mathrm{K}_{\mathrm{H}}$ right.

Table 2: $\quad$ Calculated and effective U-values.

\begin{tabular}{||c|c|c|c|c|c|c||}
\cline { 2 - 7 } House & 1 & 2 & 3 & 4 & 5 & 6 \\
\hline $\mathrm{K}_{\mathrm{H}}$ & 180 & 115 & 153 & 142 & 195 & 150 \\
\hline Theoretical U-value $\mathrm{W} / \mathrm{m}^{2} \mathrm{~K}$ & 0,53 & 0,33 & 0,31 & 0,31 & 0,35 & 0,31 \\
\hline Effective U-value $\mathrm{W} / \mathrm{m}^{2} \mathrm{~K}$ & 0,60 & 0,25 & 0,29 & 0,27 & 0,33 & 0,31 \\
& & & & & &
\end{tabular}

*Effective U-value after adding $75 \%$ of the electricity as heat gain to $\mathrm{K}$. 


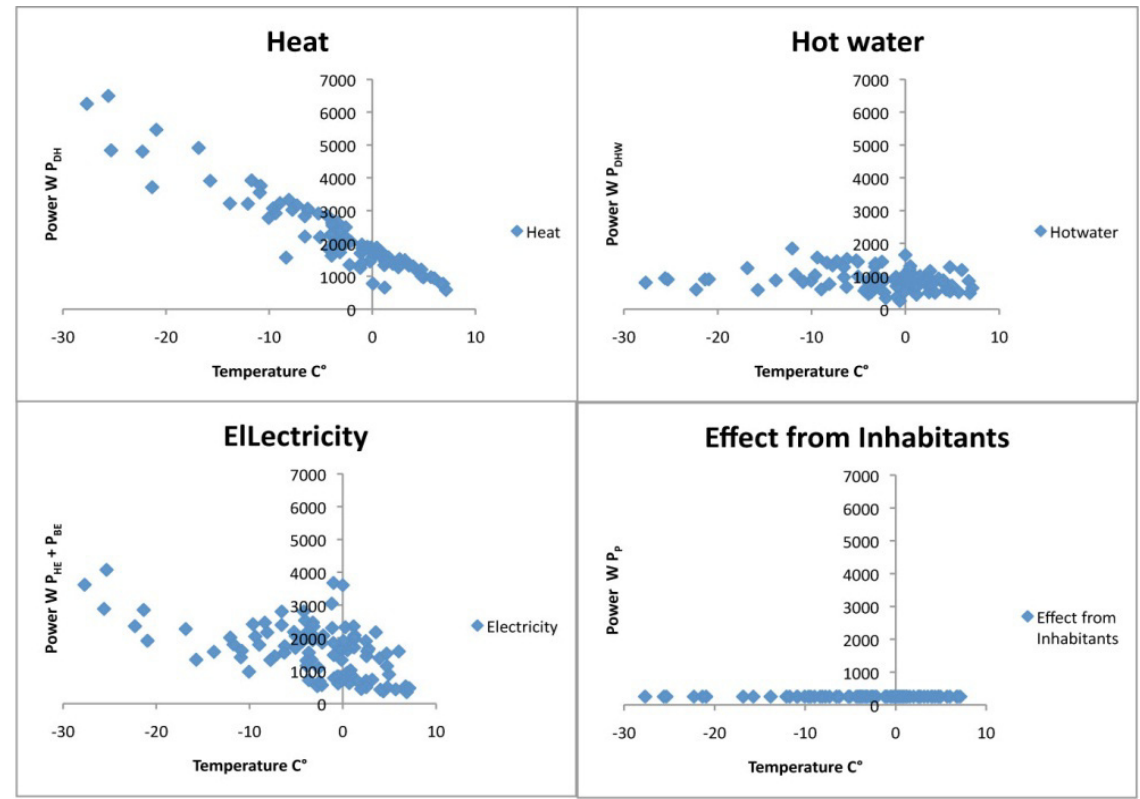

Figure 4: $\quad$ Variables dependency to outdoor temperature for house 4.

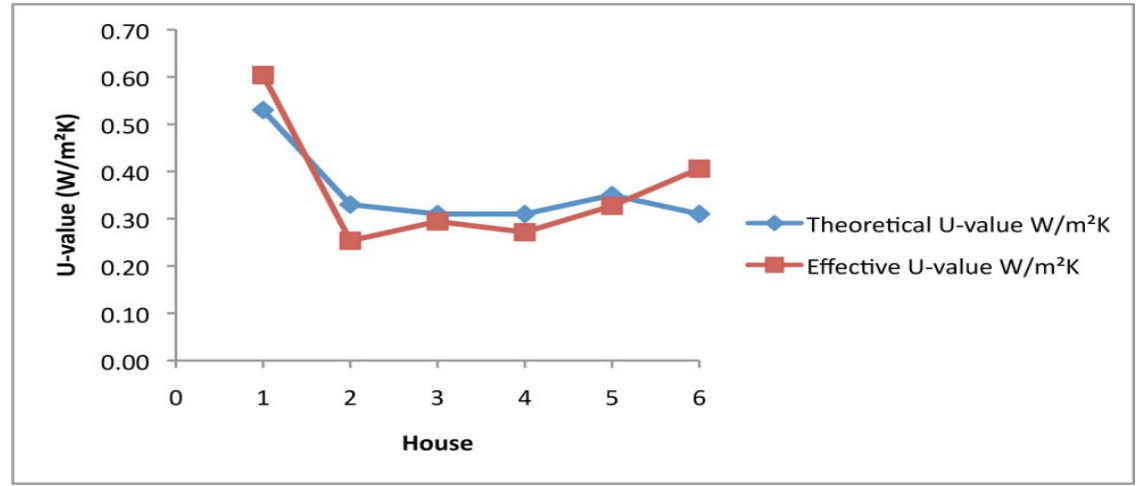

Figure 5: $\quad$ Effective vs. theoretical U-value.

\section{Discussion}

House 1-5 all show stable behaviour in measurements resulting in high $\mathrm{R}^{2}$ values. The effective and theoretical U-values are very similar. House 1 is the only house that has higher effective than theoretical U-value. A possible explanation might be the ventilation or the air tightness. This house was built in 1967 and there were no requirements or recommendation for air tightness at that time. Many builders and house owners rather had the opinion that it was good to let in more air in the house. House 2 shows a difference between effective and calculated U-values of roughly thirty per cent $\left(0.08\left(\mathrm{~W} / \mathrm{m}^{2} \mathrm{~K}\right)\right)$, nothing out of the 
ordinary can be seen on the parameter study, the graphs have a good fit with high $\mathrm{R}^{2}$ values and there is only a two per cent difference between $\mathrm{K}$ and $\mathrm{K}_{\mathrm{H}}$. In the house an older couple lives alone and they are very aware of their energy usage. It does not seem likely that the difference in U-values can be explained with resident behaviour alone. House 6 shows a clear dependency on electricity and accounting for that when deciding the effective U-value makes it rise above the calculated U-value. This house is heated with a ventilation system were it takes air from inside the building and reheat before sending it out again. If this system makes the building suck in more outdoor air and thus create an increased demand for heating is unclear and needs to be further investigated. The energy method gives good estimations of the effective U-value as long as al heat sources are accounted for and represented correctly in the model.

Although an energy signature model gives reasonable estimates of the Uvalue in a building, it is important that a large difference in temperature can be achieved. Large differences in temperature allow for the higher power usage and thus stress the building more. This is needed to acquire a good estimation of K. If a large difference in temperature cannot be achieved al measured data will gather very close to each other and become more of a ball then line, thus making a regression analysis hard to perform, thus a colder climate is an advantage. The study presented here-in have been done using a static model and both (Hammarsten [5]) and (Westergren et al. [12]) compare dynamic and static models and discuss the problem with dynamics in the building. Hammarsten recommends using daily averages while Westergren recommends using weekly. Daily averages were chosen since all houses are wooden frame houses, which is a light construction, the results suggest that this decision was correct. The results show that simple buildings with mechanical exhaust ventilation are ideal to study.

\section{Acknowledgement}

Financial support from the European Regional Development Fund via the Interreg IVA North program is gratefully acknowledged.

\section{References}

[1] L. Nordling and L. Reppen, Så Byggdes Villan : Svensk Villaarkitektur Från 1890 Tiill 2010. Forskningsrådet Formas, 2009.

[2] Energimyndigheten, "Energiläget 2011," 2012. http://www.boverket.se /Om-Boverket/Webbokhandel/Publikationer/2011/Regelsamling-forbyggande-BBR-2012/

[3] J.-U. Sjögren, S. Andersson and T.Olofsson, "An approach to evaluate the energy performance of buildings based on incomplete monthly data," Energy Build., vol. 39, pp. 945-953, 2007.

[4] J. Sjögren, Umeå universitet. Institutionen för tillämpad fysik och elektronik, Energy Performance of Multifamily Buildings: Building Characteristics and User Influence. Umeå: Department of Applied Physics and Electronics, Umeå University, 2007. 
[5] S. Hammarsten, "A critical appraisal of energy-signature models," Appl. Energy, vol. 26, pp. 97-110, 1987.

[6] Boverket, "Regelsamling för byggande, BBR," 2012. http:/www.boverket.se/Om-Boverket/Webbokhandel/Publikationer/2011/ Regelsamling-for-byggande-BBR-2012/

[7] D. C. Montgomery, Design and Analysis of Experiments. John Wiley and Sons, 2009.

[8] K. Yliniemi, "A device and a method for measurement of energy for heating tap water separated from the building's heating energy-usage," PCT/SE2006/001250, 2007.

[9] B. Petersson, Tillämpad Byggnadsfysik. Studentliteratur AB, Lund, 2010.

[10] SMHI, "SMHI Sun statistics," 2012, http://www.smhi.se/klimatdata /meteorologi/stralning/1.3054.

[11] H. J. J. Sauer, H. H. Ronald and W. J. Coad, ASHRAE Handbook, Fundamentals 2001. Amer Society of Heating, 2001.

[12] K. Westergren, H. Högberg and U. Norlén, "Monitoring energy consumption in single-family houses," Energy Build., vol. 29, pp. 247-257, $1,1999$. 